\title{
Water Requirement of Grape (Vitis vinifera) in the Northern Highlands of Yemen
}

\author{
Khader B. Atroosh ${ }^{1}$, Abdul Wahed O. Mukred ${ }^{2} \&$ Ahmed T. Moustafa ${ }^{3}$ \\ ${ }^{1}$ AREA, Elkod Agricultural Research Station, Abyan, Yemen \\ ${ }^{2}$ Agricultural Research \& Extension Authority (AREA), Dhamar, Yemen \\ ${ }^{3}$ International Center for Agricultural Research in the Dry Areas (ICARDA), Dubai Office, Dubai, UAE \\ Correspondence: Khader B. Atroosh, AREA, Elkod Agricultural Research Station, Abyan, Yemen. E-mail: \\ kbatroosh@hotmail.com
}

Received: November 9, 2012 Accepted: February 8, 2013 Online Published: March 15, 2013
$\begin{aligned} & \text { doi:10.5539/jas.v5n4p136 } \\ & \text { URL: http://dx.doi.org/10.5539/jas.v5n4p136 }\end{aligned}$

\begin{abstract}
Grape is a major fruit crop which occupies 33\% of the total area of fruit cultivation in Yemen. Grape vines are cultivated under both irrigated and rainfed production systems. The irrigation practices in grape orchards are traditional with low efficiency due to high losses of water. In order to obtain rapid and reliable results, the comparison of five equations for calculation of evapotranspiration and obtaining the Kc values by utilizing actual evapotranspiration of grape became necessary. Crop water requirement of grape trees in Sawan, Bani Hushaish District in Sana'a Governorate was studied and two methods of irrigation were investigated for two years (2005-2006). The investigated irrigation methods were: bubbler (localized) irrigation and basin irrigation. Results indicated the significant superiority of bubbler irrigation over the basin irrigation. The actual water requirements reached 601 and $736 \mathrm{~mm}$ water depth respectively with application efficiency reaching $82.6 \%$ and $69.8 \%$ respectively. The irrigation water productivity of the bubbler irrigation was significant $\left(3.8 \mathrm{~kg} / \mathrm{m}^{3}\right)$ while it was less under basin irrigation $\left(1.8 \mathrm{~kg} / \mathrm{m}^{3}\right)$. Results indicated that the average crop coefficient throughout the growing season ranged from 0.42 in the case of using Ivanov equation and 0.75 in the case of Hargreaves. In addition to standard FAO Penman-Monteith equation, the Hargreaves and Blaney-Criddle are the best equations that can be used in determination of crop water requirements and irrigation scheduling of grapes. It was also observed that the highest crop coefficient was recorded in the months of May and June in all treatments.
\end{abstract}

Keywords: basin irrigation, bubbler irrigation, water requirements, crop coefficient, grapes, Yemen

\section{Introduction}

Grapes are considered one of the most important fruits in Yemen. Total acreage occupied under grapes reaches 13488 ha producing 129385 ton (MAI, 2009). Statistics of the past five years indicates that grape cultivation occupies the third place among different fruit crops cultivated in Yemen and constitute $14.5 \%$ of the total fruit growing areas. Grape trees are cultivated in Yemen under rainfed and irrigated production systems. Supplementary irrigation are also practiced under rainfed production systems. Under all circumstances, basin irrigation is practiced and the low irrigation efficiency is evident almost everywhere. The low irrigation water efficiency is attributed to the losses of irrigation water in the earthen canals as well as in farm.

Some statistics indicate that the total irrigation water applied in grape cultivation ranges from $1342 \mathrm{~mm}$ and 740 $\mathrm{mm}$ per season. Intervals between irrigations during the summer season are 4 and 18 days respectively (Stevens \& Cole, 1987). The use of modern methods of irrigation such as drip and bubbler irrigation led to increase in yield reaching $136 \%$ and $125 \%$ respectively when compared with the pipe irrigation (Tayel, El Gindy, \& Abdel-Aziz, 2008).

Evapotranspiration is very important issue of the hydrologic budget, which differs in terms of locations and seasons. These variations require attention by water managers for good and efficient water sustainability management (Hanson, 1991). Studies of crop water requirement of grape in Yemen have not been conducted, for that there was a need to obtain knowledge on water requirement of this crop under local Yemeni conditions. In order to obtain quick and reliable results, the comparison of different equations for calculation of evapotranspiration and obtaining the Kc values by utilizing actual evapotranspiration of grape became necessary. 
Review of literature revealed that, there are several equations to calculate evapotranspiration. The equation of FAO 56-PM - Benman is the most widely applied equation on the basis of Penman -Monteith in the calculation of evapotranspiration (Allen, Pereira, Raes, \& Smith, 1998). This equation is considered a standard method of calculation despite its requirements for collection of several weather and climatic parameters such as air temperature, relative humidity, wind speed, sunshine hours as well as a series of units conversion, lengthy and complicated mathematical calculations (Cai, Liu, Lei, \& Periera, 2007). Studies conducted by (XU \& Singh, 2001) revealed that it is possible to calculate evapotranspiration in the north east of Ontario in Canada using the mathematical equations (Blaney-Criddle, Hargreaves, \& Thornwhite). Tsutsumi in Hiroshima studied the equation of Thornwhite. He concluded that evapotranspiration during winter season is minimal and not accurate (Tsutsumi, Jinno, \& Berndtsson, 2004). It is less by $10-20 \%$ when compared to Blaney-Criddle equation. The equation of Hargreaves tends to exaggerate evapotranspiration by nearly $20-30 \%$ compared to evapotranspiration calculated by Blaney-Criddle and Thornthwaite respectively. On the other hand, Thornwaite equation represents potential evaporation because of the lack of water stress in the soil (Mintz \& Walker, 1993). At earlier stages Ivanov used the relationship between air temperature and relative humidity in the calculation of evapotranspiration (Georgiev, Pafailov, Dimitrov, \& Tsonev, 1974). This approach was highlighted in several publications (Weerainghe, 1986; Dyck, 1983).

Teixeira, Bastiaanssen, and Bassoi (2007) reported that the Kc values at the initial and the end stages are highly related to the cover crop and irrigation. For wine grape, the mean weekly values in the first growing cycle were in the range from 0.65 to 0.82 , while for the second growing cycle they were from 0.63 to 0.87 . For table grape, the mean weekly average Kc values for both growing seasons varied between 0.77 and 0.91 .

Crop water productivity is defined in either physical or monetary terms as the ratio of the product (usually measured in $\mathrm{kg}$ ) over the amount of water depleted (usually limited to crop evapotranspiration, measured in $\mathrm{m}^{3}$ ). Some studies indicate that water productivity in table grape cultivation is $3.18 \mathrm{~kg} / \mathrm{m}^{3}$ of water (Yunusa, Walker, \& Guy, 1997) and $2.67-3.72 \mathrm{~kg} / \mathrm{m}^{3}$ (Nourjou, Baneh, \& Aali, 2011) while in South Africa there are indications that water productivity reached $3.7 \mathrm{~kg} / \mathrm{m}^{3}$ (Klaasse, Bastiaanssen, \& de Wit, 2007). FAO publications state that water productivity ranges from 2 to $4 \mathrm{~kg} / \mathrm{m}^{3}$ in grape trees growth under sub-tropical conditions (Doorenbos \& Kassam, 1979).

The Objective of present study is to determine the crop water requirements of grape crop under the bubbler and basin irrigation techniques and to identify crop coefficient for grape crop with the use of mathematical equations for evapotranspiration under the condition of northern highlands of Yemen.

\section{Material and Methods}

\subsection{Description of the Study Area}

This study was conducted under the Northern Highlands conditions in Sawan area in the District of Bani Hushaish in a grape fruit orchards in the vicinityof Mukhtan water reservoir at latitude ( $\left.\mathrm{N} 15^{\circ} 22^{\prime} 53.5^{\prime \prime}\right)$ and longitude (E $44^{\circ}$ $19^{\prime} 52.4^{\prime \prime}$ ) in a soil with loam to sandy loam texture and altitude $2190 \mathrm{~m}$ above sea level. Climatic data, temperature, relative humidity of the air, wind speed, hours of sunshine and the rainfall were recorded for two subsequent seasons of the study are reflected in (Table 1). It can be observed from the data in Table 1 that the average temperature ranged from $20^{\circ} \mathrm{C}$ in March to $23.3^{\circ} \mathrm{C}$ in June 2005 and from $18.9^{\circ} \mathrm{C}$ in March to $24^{\circ} \mathrm{C}$ in June 2006 . The average relative humidity of the air was generally low and did not exceed $55 \%$. The maximum speed of wind found to be 2.7 meter per second in June 2005 and 3.5 meter per second in May 2006.

\subsection{Soil and Water Measurements}

Soil samples were taken from $100 \mathrm{~cm}$ depth and the soil water physical characteristics such as field water capacity, wilting point, available moisture and bulk density were analyzed in the central laboratory of the Agricultural Research and Extension authority (AREA) in Dhamar Governorate. Chemical analysis of the irrigation water revealed that the salinity (Ec) in this well was $0.47 \mathrm{dSm}^{-1}, \mathrm{pH} 8$, SAR 1.92, RSC1.6. These results confirm the suitability of irrigation water for grape trees.

The study was conducted on 20 grape trees. The black grape variety was planted at $5 \times 5$ meters spacing. Ten trees were allocated for bubbler irrigation methods and the other ten trees for basin irrigation as per farmer's practices in irrigation without interference in irrigation scheduling or the amount of water applied per irrigation. The amount of water entered the plot and the amount of water under bubbler irrigation was determined using a scaled barrow. The discharge of water in the pipes when entered the plots was 8 liters per second and the discharge in the bubblers was 400 liters per hour. Soil moisture samples were taken at a depth of $100 \mathrm{~cm}$ before and after each irrigation to 
determine the amount of water stored in the soil after irrigation using the weighing method. The actual crop evapotranspiration of grape was estimated by using the water balance equation as per the following:

$$
\mathrm{ETc}=\mathrm{SWin}-\mathrm{SWE}+\text { Irr. }+\mathrm{W}_{\mathrm{s}}+\text { Ref }
$$

Where,

$\mathrm{ETc}=$ Actual crop evapotranspiration; SWin $(\mathrm{mm})=$ soil moisture at the beginning; SWE $=$ soil moisture at the end $(\mathrm{mm})$; Irr. = Amount of irrigation water $(\mathrm{mm}) ; \mathrm{Ws}=$ Spate water $(\mathrm{mm})$; Ref = Effective rainfall which was calculated by using FAO CROPWAT software - equation of USDA soil conservation service.

Table 1. Climatic parameters during 2005 and 2006

\begin{tabular}{|c|c|c|c|c|c|c|c|c|}
\hline \multirow{2}{*}{ Year } & \multirow{2}{*}{ Month } & \multicolumn{3}{|c|}{ Temperature $\left({ }^{\circ} \mathrm{C}\right)$} & \multirow{2}{*}{ Humidity (\%) } & \multirow{2}{*}{$\begin{array}{l}\text { Wind } \\
(\mathrm{m} / \mathrm{s})\end{array}$} & \multirow[t]{2}{*}{ speed } & \multirow{2}{*}{ Sunshine, hour } \\
\hline & & Max & Min & Mean & & & & \\
\hline \multirow{8}{*}{2005} & March & 27.9 & 12 & 20.0 & 53 & 2.2 & & 8.6 \\
\hline & April & 26.6 & 11.2 & 18.9 & 48 & 2 & & 8.8 \\
\hline & May & 29 & 13.3 & 21.2 & 42 & 2.2 & & 8.7 \\
\hline & June & 30.8 & 15.3 & 23.1 & 32 & 2.7 & & 10.3 \\
\hline & July & 30.2 & 16.4 & 23.3 & 48 & 2.4 & & 6.7 \\
\hline & August & 30.4 & 15.8 & 23.1 & 43 & 2.3 & & 7.0 \\
\hline & September & 29 & 14 & 21.5 & 33 & 2.6 & & 9.0 \\
\hline & October & 25.1 & 7.8 & 16.5 & 32 & 1.9 & & 10.6 \\
\hline \multirow{8}{*}{2006} & March & 27.7 & 10 & 18.9 & 47 & 2.8 & & 8.0 \\
\hline & April & 27.9 & 11.9 & 19.9 & 47 & 3.1 & & 8.7 \\
\hline & May & 30.4 & 14.3 & 22.4 & 36 & 3.5 & & 8.5 \\
\hline & June & 31.6 & 15.2 & 23.4 & 28 & 3.4 & & 9.5 \\
\hline & July & 31.5 & 16.4 & 24.0 & 46 & 3.3 & & 6.5 \\
\hline & August & 29.4 & 15.6 & 22.5 & 55 & 3.2 & & 7.2 \\
\hline & September & 28.7 & 13.3 & 21 & 34 & 3.1 & & 8.6 \\
\hline & October & 27 & 9.8 & 18.4 & 28 & 3 & & 9.6 \\
\hline
\end{tabular}

\subsection{Potential Evapotranspiration Equations (ETo)}

Crop water requirements (CWR) is defined as the amount of water required to compensate the evapotranspiration loss from the cropped field (Allen et al, 1998). For this study we used five equations for calculation of potential evapotranspiration (ETo). The estimation of ETo based on climatic data for the period of the study was done by utilizing the following equations.

\subsubsection{FAO Penman-Monteith Method}

The FAO Penman-Monteith method for calculating reference (potential) evapotranspiration $\mathrm{ET}_{0}$ can be expressed as (Allen et al., 1998):

$$
\mathrm{ET}_{0}=\frac{0.408 \Delta\left(R_{n}-G\right)+\gamma \frac{900}{T+273} u_{2}\left(e_{s}-e_{3}\right)}{\Delta+\gamma\left(1+0.34 u_{2}\right)}
$$

Where ETo is reference evapotranspiration $\left[\mathrm{mm} \mathrm{day}^{-1}\right], \mathrm{Rn}$ is net radiation at the crop surface $\left[\mathrm{MJ} \mathrm{m}^{-2} \mathrm{day}^{-1}\right]$, $\mathrm{G}$ is soil heat flux density $\left[\mathrm{MJ} \mathrm{m}^{-2}\right.$ day $\left.^{-1}\right], \mathrm{T}$ is mean daily air temperature at $2 \mathrm{~m}$ height $\left[{ }^{\circ} \mathrm{C}\right]$, $\mathrm{u} 2$ is wind speed at 2 $\mathrm{m}$ height $\left[\mathrm{m} \mathrm{s}^{-1}\right]$, es is saturation vapour pressure $[\mathrm{kPa}]$, ea is actual vapour pressure $[\mathrm{kPa}]$, (es - ea) is saturation vapour pressure deficit $[\mathrm{kPa}], \Delta$ is slope vapour pressure curve $\left[\mathrm{kPa}^{\circ} \mathrm{C}^{-1}\right], \gamma$ is psychrometric constant $\left[\mathrm{kPa}^{\circ} \mathrm{C}^{-1}\right]$. 


\subsubsection{Hargreaves Method}

The 1985 Hargreaves-Samani method requires only maximum and minimum daily air temperature and solar energy. It has the form:

$$
\mathrm{ET}_{\mathrm{o}}=0.0023\left(\mathrm{~T}_{\max }-\mathrm{T}_{\min }\right)^{0.5}\left(\mathrm{~T}_{\text {mean }}+17.8\right) \mathrm{R}_{\mathrm{a}}
$$

Where ETo is potential evapotranspiration, $\mathrm{mm} \mathrm{d}^{-1}, \mathrm{~T}_{\max }$ is maximum daily air temperature ${ }^{\circ} \mathrm{C}, \mathrm{T}_{\min }$ is minimum daily air temperature ${ }^{\circ} \mathrm{C}, \mathrm{T}_{\text {mean }}$ is mean daily air temperature, computed as $\left(\mathrm{T}_{\max }+\mathrm{T}_{\min }\right) / 2, \mathrm{R}_{\mathrm{a}}$ is extraterrestrial radiation $\mathrm{mm} \mathrm{d}^{-1}, \mathrm{R}_{\mathrm{a}}$ in $\mathrm{mm} \mathrm{d}^{-1}=\mathrm{R}_{\mathrm{a}}$ in $\mathrm{MJ} \mathrm{m}^{-2} \mathrm{~d}^{-1} / 2.45$.

\subsubsection{Blaney-Criddle method}

The Blaney-Criddle procedure for estimating ET is well known in the western U.S.A. and has been used extensively elsewhere. The usual form of the Blaney-Criddle equation converted to metric units written as:

$$
\mathrm{ET}_{\mathrm{o}}=\mathrm{P}\left(0.46 * \mathrm{~T}_{\text {mean }}+8\right)
$$

Where ETo is Reference crop evapotranspiration ( $\mathrm{mm} /$ month), T mean is mean monthly $\left({ }^{\circ} \mathrm{C}\right), \mathrm{p}=$ mean monthly percentage of annual daytime hours.

\subsubsection{Thornthwaite Method}

The Thornthwaite equation given by Thornthwaite in 1948. It has the following form:

$$
\mathrm{ETo}=16\left(\frac{10 T}{I}\right)^{a}
$$

Where $\mathrm{T}_{\text {is }}$ the monthly mean temperature (C), I is the heat index for the year, given by:

$I=\sum i=\Sigma\left(\frac{T}{5}\right)^{1.5}$

$a=0.49+0.0179 I-0.0000771 I^{2}+0.000000675 I^{3}$.

\subsubsection{Ivanov Method}

The method of Ivanov cited by Georgiev et al. (1974) stressed the relationship between temperature and relative humidity to estimate the potential evapotranspiration as the following equestion:

$$
\mathrm{ET}_{\mathrm{O}}=0.0018(\mathrm{~T}+25)^{2} *(100-\mathrm{RH})
$$

Where $\mathrm{T}$ is the monthly mean temperature (C), $\mathrm{RH}$ is relative humidity (\%).

\subsubsection{Crop Coefficient (Kc) Estimation}

The crop coefficient $(\mathrm{Kc})$ was estimated by dividing the actual crop water requirement on the estimated potential evapotranspiration at different mathematical levels as per the following equation:

$$
\mathrm{Kc}=\mathrm{ETc} / \mathrm{ETo}
$$

Where $\mathrm{Kc}$ is crop coefficient, ETc is actual crop evapotranspiration and ETo is potential evapotranspiration.

For comparing the studied equation with consideration to ET FAO Penman-Monteith as standard method, the percentage errors in averages evapotranspiration estimates were calculated by using the following equation stated by $\mathrm{Xu}$ and Singh (2001):

Percentage Error $=[100 \times($ ETo - ET FAO Penman-Monteith $) /$ ET FAO Penman-Monteith $]$

Where ETo is estimated potential evapotranspiration; FAO Penman-Monteith: is evapotranspiration estimated by standard FAO -56 question.

\subsection{Statistical Analyses}

Two treatments were applied, with each treatment replicated ten times in completely randomized Block Design. Similarly the excel program version 2.0. Software was used to calculate evapotranspiration (De Pauw, 1999). All data were analyzed following standard procedures for analysis of variance (ANOVA) and differences between means were compared for significance at $\mathrm{P}=0.05$ and $\mathrm{P}=0.01$. In the study, the Genstat program (Lane \& Payne, 1996) was used to conduct statistical analysis of the different treatments. 


\section{Results and Discussion}

\subsection{Applied Irrigation Water}

Table (2) illustrates the water physical characteristics of the soil field capacity, wilting point, available water, and bulk density at the $100 \mathrm{~cm}$ depth. The soil moisture content at the field capacity and wilting point were 230 and 128 $\mathrm{mm}$ respectively, while the available water reached $102 \mathrm{~mm}$ and the average bulk density for the same depth reached $1.45 \mathrm{gm} / \mathrm{cm}^{3}$.

Table 2. Soil water content at wilting point, field capacity and available water and bulk density

\begin{tabular}{|c|c|c|c|c|c|c|c|c|}
\hline \multirow{2}{*}{ Depth, cm } & \multirow{2}{*}{$\begin{array}{l}\text { Bulk } \\
\mathrm{g} / \mathrm{cm}^{3}\end{array}$} & \multirow{2}{*}{ density, } & \multicolumn{2}{|c|}{ Wilting Point } & \multicolumn{2}{|c|}{ Field Capacity } & \multicolumn{2}{|c|}{ Available Water } \\
\hline & & & $\%$ & $\mathrm{~mm}$ & $\%$ & $\mathrm{~mm}$ & $\%$ & $\mathrm{~mm}$ \\
\hline $0-20$ & 1.48 & & 8.1 & 24.0 & 14.9 & 44.1 & 6.8 & 20.1 \\
\hline $20-40$ & 1.47 & & 8.2 & 24.1 & 15 & 44.1 & 6.8 & 20.0 \\
\hline $40-60$ & 1.46 & & 8.9 & 26.0 & 15.1 & 44.1 & 6.2 & 18.1 \\
\hline $60-80$ & 1.44 & & 9 & 25.9 & 16.7 & 48.1 & 7.7 & 22.2 \\
\hline $80-100$ & 1.42 & & 9.9 & 28.1 & 17.6 & 50.0 & 7.7 & 21.9 \\
\hline $0-100$ & 1.45 & & 8.8 & 128.1 & 15.9 & 230.4 & 7.0 & 102.3 \\
\hline
\end{tabular}

Table 3. Irrigation water applied for grape trees during the years of study

\begin{tabular}{llllll}
\hline \multirow{2}{*}{ Year } & Date & $\begin{array}{l}\text { Bubbler } \\
\text { Irrigation, } \mathrm{mm}\end{array}$ & $\begin{array}{l}\text { Application } \\
\text { Efficiency, \% }\end{array}$ & $\begin{array}{l}\text { Basin } \\
\text { Irrigation, } \mathrm{mm}\end{array}$ & $\begin{array}{l}\text { Application } \\
\text { Efficiency, \% }\end{array}$ \\
\hline \multirow{3}{*}{2005} & $14 / 3 / 2005$ & 45 & 86.5 & 75 & 68.2 \\
& $21 / 4 / 2005$ & 30 & 78.9 & 60 & 70.6 \\
& $6 / 5 / 2005$ & 32 & 84.2 & 70 & 70.0 \\
& $10 / 9 / 2005$ & 35 & 83.3 & 80 & 66.7 \\
& Total & 142 & 83.5 & 285 & 68.9 \\
& $8 / 3 / 2006$ & 54 & 83.1 & 73 & 66.4 \\
& $18 / 4 / 2006$ & 53 & 81.5 & 71 & 61.7 \\
& $15 / 5 / 2006$ & 53 & 81.5 & 71 & 71.0 \\
& $12 / 6 / 2006$ & 54 & 83.1 & 73 & 73.0 \\
& $2 / 7 / 2006$ & 55 & 84.6 & 73 & 69.5 \\
& $3 / 8 / 2006$ & 54 & 83.1 & 72 & 75.8 \\
& $10 / 9 / 2066$ & 53 & 81.5 & 71 & 71.0 \\
& Total & 376 & 82.6 & 504 & 69.8 \\
\hline
\end{tabular}

Table (3) illustrates the amounts and timing of irrigation. It was noted that the total amount of water per irrigation in the year 2005 ranged from 30 to $45 \mathrm{~mm}$ in the bubbler irrigation method and 60 to $80 \mathrm{~mm}$ in the case of basin irrigation method, While in the year 2006 the total amount of water per irrigation under bubbler and basin irrigation methods were $53-55 \mathrm{~mm}$ and $71-73 \mathrm{~mm}$ respectively. Therefore, the total irrigation water applied and stored in the soil during the year 2005 was $142 \mathrm{~mm}$ in the bubbler and $285 \mathrm{~mm}$ water depth in the case of basin irrigation, while the amount of irrigation water applied and stored in the soil in the 2006 was 376 and $504 \mathrm{~mm}$ respectively with average application efficiency reaching $82.6 \%$ and $69.8 \%$ respectively. The differences in amount of applied water between the years of study can be attributed to fluctuation of the amount of rainfall in the two seasons of study. On the other hand, the differences between the methods of irrigation suggest that there is a considerable amount of water wasted through deep percolation and evaporation from the surface of the soil in the case of basin irrigation compared to bubbler irrigation where irrigation water was localized directly under each tree. The volume of water applied per grape tree was about 50 to $25 \%$ less in the bubbler than basin for the years of study respectively. 


\subsection{Actual Evapotanspiration}

The water requirements of grape differ as per the applied irrigation method. In the case of basin irrigation, the water requirements are much higher when compared to bubbler irrigation. The actual crop evapotranspiration (Etc) in the case of basin irrigation was 783 and $689 \mathrm{~mm}$ during the duration of the study (2005 and 2006) respectively, with an average of $736 \mathrm{~mm}$ for two seasons. In the case of bubbler irrigation, the crop evapotranspiration (Etc) ranged from 640 - $561 \mathrm{~mm}$ water depth during the two seasons of the study (2005 and 2006) with an average of 601 for both seasons (Table 4). It can be also noted that the actual crop evapotranspiration (Etc) in the year 2005 was more than the year 2006. This is attributed to the flow of large amount of floods on the 21st May and 12th July 2005. The amount of floods was in the range of 180 and $300 \mathrm{~mm}$ water depth respectively (Table 5).

Table 4. Actual evapotanspiration $(\mathrm{mm})$ of grape under basin and bubbler irrigation

\begin{tabular}{llllllll}
\hline \multirow{2}{*}{ Month } & \multicolumn{3}{l}{ Basin Irrigation } & & \multicolumn{3}{c}{ Bubbler Irrigation } \\
\cline { 2 - 3 } \cline { 7 - 9 } & 2005 & 2006 & Average & & 2005 & 2006 & Average \\
\hline March & 71 & 78 & 74 & & 62 & 62 & 62 \\
April & 105 & 93 & 99 & & 93 & 75 & 84 \\
May & 149 & 127 & 138 & & 112 & 96 & 104 \\
June & 156 & 132 & 144 & & 120 & 102 & 111 \\
July & 127 & 109 & 118 & & 105 & 84 & 95 \\
August & 93 & 68 & 81 & & 74 & 62 & 68 \\
September & 60 & 63 & 62 & & 54 & 57 & 56 \\
October & 22 & 20 & 21 & & 20 & 23 & 21 \\
Total & 783 & 689 & 736 & & 640 & 561 & 601 \\
\hline
\end{tabular}

\subsection{Water Productivity}

Irrigation technology has an important and a significant impact on the amount of water-use in grape production. The yield of grapes irrigated by bubbler system was significantly higher than that of the control (Basin irrigation). There was significant decrease in water use due to bubbler irrigation system adopted in grape cultivation, compared to the traditional basin irrigation.

The application of bubbler irrigation technology reduces the amount of water-use by $1350 \mathrm{~m}^{3}$ per hectare compared to the use of the traditional basin irrigation method with an average increase in yield being 6.8 ton/ha (Table 5).

Table 5. Water use efficiency of grape under basin and bubbler irrigation methods

\begin{tabular}{|c|c|c|c|c|c|c|c|c|}
\hline \multirow{2}{*}{ Years } & \multirow{2}{*}{$\begin{array}{l}\text { Method of } \\
\text { irrigation }\end{array}$} & \multirow{2}{*}{$\begin{array}{l}\text { Rain } \\
\mathrm{mm}\end{array}$} & \multirow{2}{*}{$\begin{array}{l}\text { Spate } \\
\mathrm{mm}\end{array}$} & \multicolumn{2}{|l|}{ Irrigation } & \multirow{2}{*}{$\begin{array}{l}\text { Etc } \\
\mathrm{m}^{3} / \mathrm{ha}\end{array}$} & \multirow{2}{*}{$\begin{array}{l}\text { Yield } \\
\text { Ton/ha }\end{array}$} & \multirow{2}{*}{$\begin{array}{l}\text { WUE } \\
\mathrm{Kg} / \mathrm{m}^{3}\end{array}$} \\
\hline & & & & Number & $\mathrm{mm}$ & & & \\
\hline \multirow{2}{*}{2005} & Bubbler & 218 & 280 & 4 & 142 & 6400 & 20 & 3.1 \\
\hline & Farmer & 218 & 280 & 4 & 285 & 7830 & 11.2 & 1.4 \\
\hline \multirow{2}{*}{2006} & Bubbler & 185 & - & 7 & 376 & 5610 & 20.8 & 3.7 \\
\hline & Farmer & 185 & - & 7 & 504 & 6890 & 16 & 2.3 \\
\hline \multirow{2}{*}{ Mean } & Bubbler & - & - & - & - & 6010 & 20.4 & 3.4 \\
\hline & Farmer & - & - & - & - & 7360 & 13.6 & 1.8 \\
\hline \multicolumn{2}{|c|}{$\mathrm{Sd}=929.135$} & $=464.567$ & & $\%=13.904$, & $t=14.38$ & 8, L.S.D. = & $=2.382$ & $\mathrm{p}=<0.001$ \\
\hline
\end{tabular}

The average yields of fresh grape under bubbler and basin irrigation were 20.4 and 13.6 ton/ha respectively. The increase in yield under bubbler irrigation can be attributed to the fact that over irrigation under basin method has negative effect of nutrients and water uptake by the root system and disturbs the oxygen balance of the root zone 
(Irmak \& Rathje, 2008). The water productivity under bubbler irrigation of grape during the two years study was 3.1 and 3.7 respectively, with an average of $3.4 \mathrm{~kg} / \mathrm{m}^{3}$, while the water productivity under basin irrigation of grape during the two years of study was 1.4 and 2.3 respectively, with an average of $1.8 \mathrm{~kg} / \mathrm{m}^{3}$. These findings confirm the superiority of bubbler irrigation method in comparison with the basin irrigation method. These results are in agreement with previous studies, (Yunusa et al., 1997; Klaasse et al., 2007; El Gendy, 2012). The estimated coefficient of the variation of the irrigation technology was $13.9 \%$ as an average for the two years. Significant differences were detected between methods of irrigation $\mathrm{P} \leq 0.001$ (Table, 5).

\subsection{Estimated Potential Evapotranspiration}

Table (6) demonstrates potential evapotranspiration calculated by the selected mathematical equations. Ivanov equation recorded the highest rate of evaporatranspiration 1783.1 and $1848.8 \mathrm{~mm}$ water depth for the growing period of grapes (1 March - 13 October) during the two seasons of the study respectively. The lowest rates of evaporatranspiration recorded in the case of using Thornthwaite equation $779.9 \mathrm{~mm}$ and 791.7 respectively. In the case of using FAO Penman-Monteith equation as a standard equation, the results were $1337.3 \mathrm{~mm}$ and $1439.1 \mathrm{~mm}$ respectively. These results are in confirmation with results published by Xu and Singh (2001) and Tsutsumi et al. (2004).

Table 6. Reference evapotranspiration (ETo) in ( $\mathrm{mm}$ ) and crop coefficient (Kc) of grape

\begin{tabular}{lccccccccc}
\hline ETo 2005 & & & & & & & & & \\
ETO METHODS & Mar & \multicolumn{1}{c}{ Apr } & May & Jun & Jul & Aug & Sep & Oct & Total \\
ETo_FAO 56 & 170.1 & 175.0 & 188.5 & 195.5 & 177.8 & 186.7 & 180.1 & 63.7 & 1337.3 \\
ETo_Hargreaves & 157.4 & 154.6 & 173.4 & 174.1 & 170.5 & 173.0 & 156.1 & 57.9 & 1217.2 \\
ETo_Blaney-Criddle & 179.7 & 175.4 & 198.0 & 203.8 & 210.4 & 204.2 & 183.3 & 66.7 & 1421.6 \\
ETo_Thornthwaite & 93.3 & 83.6 & 108.8 & 117.6 & 126.8 & 122.0 & 99.0 & 28.6 & 779.9 \\
ETo_Ivanov & 170.9 & 180.4 & 222.4 & 282.6 & 218.4 & 237.4 & 260.8 & 91.1 & 1663.9 \\
Average & 154.3 & 153.8 & 178.2 & 194.7 & 180.8 & 184.7 & 175.9 & 85.4 & 1307.8 \\
\hline ETo 2006 & & & & & & & & & \\
ETo_FAO 56 & 178.8 & 2 & 211.3 & 206.0 & 194.6 & 194.1 & 186.4 & 72.7 & 1439.1 \\
ETo_Hargreaves & 161.2 & 161.9 & 181.1 & 180.7 & 181.2 & 165.8 & 156.1 & 61.0 & 1249.0 \\
ETo_Blaney-Criddle & 174.5 & 180.2 & 204.1 & 205.5 & 213.8 & 201.2 & 181.0 & 70.5 & 1430.8 \\
ETo_Thornthwaite & 85.4 & 90.1 & 118.0 & 120.1 & 132.0 & 117.1 & 95.3 & 33.7 & 791.7 \\
ETo_Ivanov & 183.4 & 192.3 & 258.3 & 303.6 & 232.9 & 182.8 & 251.4 & 105.8 & 1527.0 \\
Average & 156.7 & 163.9 & 194.6 & 203.2 & 190.9 & 172.2 & 174.0 & 96.4 & 1351.9 \\
\hline
\end{tabular}

Comparing the rates of evaporatranspiration at the different levels under investigation with FAO Penman-Monteith equation, it suggests that the Hargreaves and Blaney-Criddle equations were almost close with FAO Penman-Monteith equation values. Figure 1 shows the percentage errors of selected equations. In this figure, the percentage error was less than those values calculated by Penman-Monteith equation throughout the growing months except the month of July where the values of percentage error calculated by Blaney-Criddle exceeded those values calculated by FAO Penman-Monteith. This indicates that the more applicable equation for calculation of potential evapotranspiration under irrigated grape grown in the highlands of Yemen are Hargreaves and Blaney-Criddle.

\subsection{Crop Coefficient (Kc)}

The values of crop coefficient $(\mathrm{Kc})$ were derived from the relationship between actual water consumption and the potential evapotranspiration calculated based on the use of mathematical equations. It was observed that the highest crop coefficient values $(\mathrm{Kc})$ were obtained by Thornthwaite equation where the average of the total growing period for the two years of study were 0.83 and 0.91 for bubbler and basin irrigation methods respectively, while the lowest values of $(\mathrm{Kc})$ derived by Ivanov equation were 0.35 and 0.42 respectively. The Kc values at all equations were highest during June in comparison with the other months; this increase was probably caused by 
more rapid development of grape tree under the warmer atmospheric conditions. Similar results were found by Myburgh (2012). The obtained average values of $(\mathrm{Kc})$ for grape under bubbler irrigation were 0.44 and 0.47 using Blaney-Criddle and Hargreaves equations respectively, while the average values of $(\mathrm{Kc})$ for grape under basin irrigation were 0.50 and 0.57 using Blaney-Criddle and Hargreaves equations respectively. These data are close to (Kc) calculated by FAO Penman-Monteith equation (Table 7) and confirm the results of previous studies carried out by Teixeira et al. (2007) and Myburgh (2012).

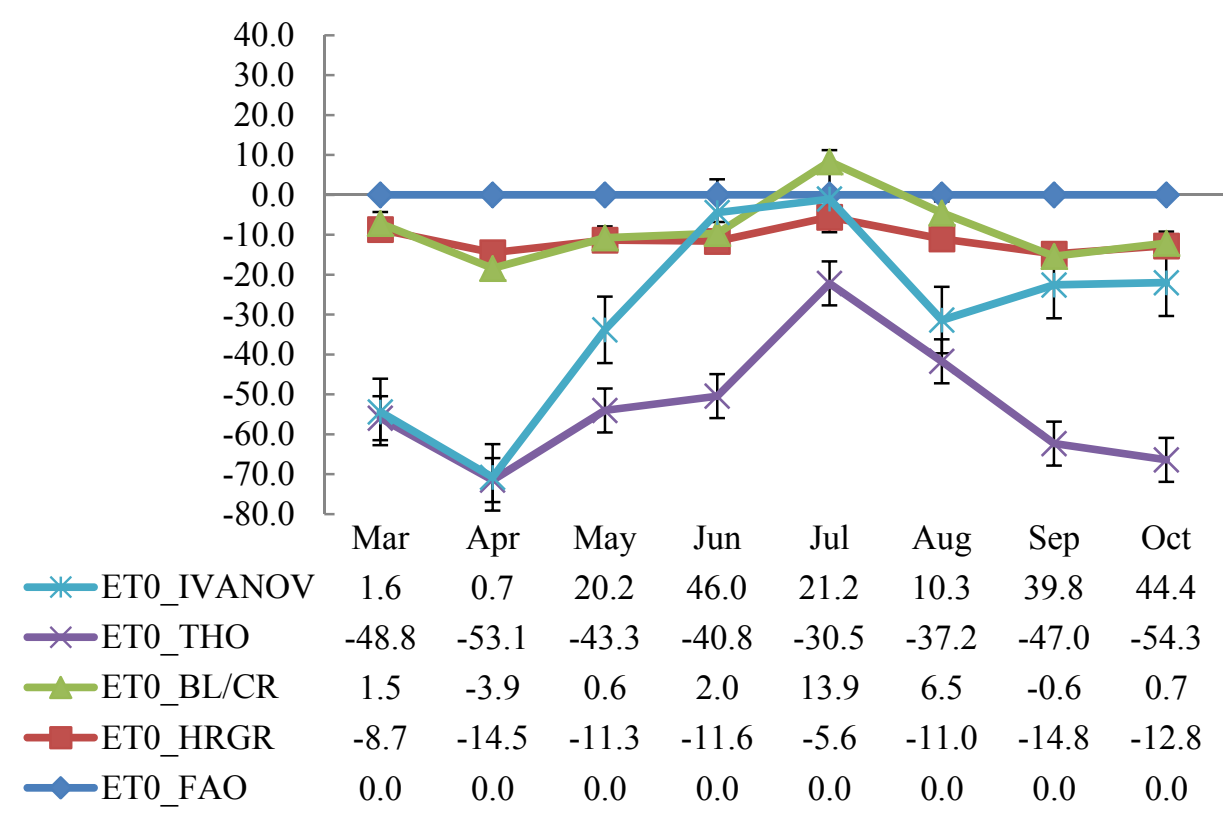

Figure 1. Pecentage error in average evapotranspiration estimates

Table 7. Estimated Crop coefficient of Grape crop by using different evapotranspiration equations

\begin{tabular}{|c|c|c|c|c|c|c|c|c|c|}
\hline \multicolumn{10}{|c|}{ Crop Coefficient (Kc) for Bubbler Irrigated Grape } \\
\hline ETo_Methods & Mar & Apr & May & Jun & Jul & Aug & Sep & Oct & Total \\
\hline ETo_FAO 56 & 0.36 & 0.46 & 0.52 & 0.55 & 0.51 & 0.36 & 0.30 & 0.32 & 0.42 \\
\hline ETo_Hargreaves & 0.39 & 0.53 & 0.59 & 0.63 & 0.54 & 0.40 & 0.36 & 0.36 & 0.47 \\
\hline ETo_Blaney-Criddle & 0.35 & 0.44 & 0.51 & 0.53 & 0.45 & 0.36 & 0.56 & 0.31 & 0.44 \\
\hline ETo_Thornthwaite & 0.73 & 0.84 & 0.88 & 0.90 & 0.75 & 0.64 & 1.24 & 0.69 & 0.83 \\
\hline ETo_Ivanov & 0.35 & 0.45 & 0.44 & 0.38 & 0.42 & 0.33 & 0.22 & 0.22 & 0.35 \\
\hline Average & 0.44 & 0.55 & 0.59 & 0.60 & 0.53 & 0.42 & 0.54 & 0.38 & 0.50 \\
\hline Sd. & 0.17 & 0.17 & 0.17 & 0.19 & 0.13 & 0.13 & 0.42 & 0.18 & 0.19 \\
\hline C.V. & 38.2 & 31.2 & 29.4 & 31.7 & 24.0 & 30.6 & 77.4 & 47.8 & 37.7 \\
\hline \multicolumn{10}{|c|}{ Crop Coefficient Kc for Basin Irrigated Grape } \\
\hline ETo_FAO 56 & 0.43 & 0.54 & 0.70 & 0.72 & 0.64 & 0.42 & 0.34 & 0.31 & 0.51 \\
\hline ETo_Hargreaves & 0.47 & 0.63 & 0.78 & 0.81 & 0.67 & 0.47 & 0.39 & 0.35 & 0.57 \\
\hline ETo_Blaney-Criddle & 0.42 & 0.56 & 0.69 & 0.70 & 0.56 & 0.40 & 0.34 & 0.31 & 0.50 \\
\hline ETo_Thornthwaite & 0.84 & 1.14 & 1.22 & 1.21 & 0.91 & 0.67 & 0.63 & 0.68 & 0.91 \\
\hline ETo_Ivanov & 0.42 & 0.53 & 0.58 & 0.49 & 0.52 & 0.38 & 0.24 & 0.22 & 0.42 \\
\hline Average & 0.51 & 0.68 & 0.79 & 0.79 & 0.66 & 0.47 & 0.39 & 0.37 & 0.58 \\
\hline Sd. & 0.18 & 0.26 & 0.25 & 0.26 & 0.15 & 0.12 & 0.15 & 0.18 & 0.19 \\
\hline C.V. & 35.2 & 38.6 & 31.5 & 33.5 & 23.2 & 25.2 & 38.1 & 48.0 & 33.0 \\
\hline
\end{tabular}




\section{Conclusions}

The bubbler irrigation method appeared to be more efficient in terms of water use and water saving and led to significant increase in yield compared to the basin irrigation. The water productivity under bubbler irrigation reached $3.4 \mathrm{~kg} / \mathrm{m}^{3}$ compared to $1.8 \mathrm{~kg} / \mathrm{m}^{3}$ under basin irrigation. The average water consumption for grape was $22.5 \%$ less compared to basin irrigation. Therefore, the application of bubbler irrigation method in grape orchards is a potential water saving technology towards achieving the sustainable water management in Yemen, which suffers from water scarcity and is a limiting factor of agricultural expansion. Five equations were studied to determine evapotranspiration under the conditions of Sawan district in Bani Hushaish, northern highlands of Yemen. The average values of $(\mathrm{Kc})$ ranged from 0.50 to 0.58 under bubbler and basin method respectively. The kc values determined in this study could be useful tool for estimations of ETc for bubbler and basin irrigation. It was concluded that Hargreaves and Blaney-Criddle are the best equations for determination of crop water requirements and irrigation scheduling of grapes that can be used under local Yemeni conditions in addition to standard FAO Penman-Monteith equation. The finding of this study supports the global trend which is directed to avoid water wastage and divert to application of more efficient methods of irrigation.

\section{References}

Allen, G. R., Pereira, L. S., Raes, D., \& Smith, M. (1998). Crop Evapotranspiration-Guidelines for computing crop water requirements. FAO Irrigation and Drainage Paper 56. FAO, Rome, Italy.

Cai, J., Liu, Y., Lei, T., \& Periera, L. S. (2007). Estimating reference evapotranspiration with the FAO Penman-Monteith equation using daily weather forecast messages. Agricultural and Forest Meteorology, 145(1-2, 9), 22-35. http://dx.doi.org/10.1016/j.agrformet.2007.04.012

De Pauw, E. (1999). Potential Evapotranspiration, Version 2.0. Software prepared for the Regional Training Course "Improving On-Farm Water Use Efficiency", ICARDA, 10-21 October 1999, ICARDA.

Doorenbos, J., \& Kassam, A. H. (1979). Yield response to water. FAO Irrigation and draining Paper No. 33. FAO, Rome, Italy.

Dyck, S. (1983). Overview on present status of the concepts of water balance module, A new approaches in water balance computations. Proceeding of the Hamburg workshop, August, 1983, IAHS Pub.no. 148.

El Gendy, R. S. S. (2012). Water Requirements of Grafted Grape Vines under Desert Land Conditions. Journal of $\begin{array}{lllll}\text { Horticultural Science } \quad \& \quad \text { Ornamental } & \text { Plants, } & 4(3), & \text { 345-364. }\end{array}$ http://dx.doi.org/10.5829/idosi.jhsop.2012.4.3.266

Georgiev, G., Pafailov, P., Dimitrov, Z., \& Tsonev, S. (1974). Exercise Book of Agricultural Melioration for Students of Higher Agricultural Institute-Plovdiv (p. 46). Xristo G. Danov, Plovdiv (In Bulgarian).

Hanson, R. L., (1991). Evapotranspiration and drought. In R. W. Paulson, E. B. Chase, R. S. Roperts, \& D. W. Mody (Eds.), Compilers, National Water Summary 1988-89-Hydrolic Events and Floods and Droughts: U. S. Geological Survey Water-Supply Paper 2375 (pp. 99-104).

Irmak, S., \& Rathje, W. R. (2008). Plant growth and yield as affected by wet soil conditions due to flooding or over irrigation. Publications of University of Nebraska-Lincoln Extension. Institute of Agriculture and resources, Neb Guide, G1904.

Klaasse, A., Bastiaanssen, W. G. M., \& de Wit, M. (2007). Satellite analysis of water use efficiency in the winelands region of Western Cape, South Africa. Water Watch Report for West Cape Department of Agriculture (p. 70). Wageningen, The Netherlands.

Lane, P. W., \& Payne, R. W. (1996). Genstat for windows: an introduction course. Statistics Department, IACR-Rothamsted, Harpenden, Herts AL5 2JQ, UK, NP 3044.

Ministry of Agriculture and Irrigation (MAI). (2010). Agricultural Statistics Year Book for 2009, General Department of Agricultural Statistics, Sana'a, Yemen.

Mintz, Y., \& Walker, G. K. (1993). Global fields of soil moisture and land surface evapotranspiration derived from observed precipitation and surface air temperature. Journal of Applied Meteorology, 32, 1305-1334. http://dx.doi.org/10.1175/1520-0450(1993)032<1305:GFOSMA >2.0.CO;2

Myburgh, P. A. (2012). Comparing Irrigation Systems and Strategies for Table Grapes in the Weathered Granite-gneiss Soils of the Lower Orange River Region. S. Afr. J. Enol. Vitic., 33, 184-197. 
Nourjou, A., Baneh, H. D., \& Ali, J. A. (2011). Grapevine Yield, Quality and Water Use Efficiency Response to Deficit Irrigation, In: ICID 21st International Congress on Irrigation and Drainage, 15-23 October 2011, Tehran, Iran.

Stevens, R. M., \& Cole, P. (1987). Grape must composition depends on irrigation management. In T. Lee (Ed.), Proceedings of the sixth Australian wine industry technical conference. Australian Industrial Publishers, Adelaide, 159-64.

Tayel, M. Y., El-Gindy, A. M., \& Abdel-Aziz, A. A. (2008). Effect of irrigation systems on: III-productivity and quality of grape crop. Journal of Applied Sciences Research, 4(12), 1722-1729.

Teixeira, A. H. de C., Bastiaanssen, W. G. M., \& Bassoi, L. H. (2007). Crop water parameters of irrigated wine and table grapes to support water productivity analysis in the Sa o Francisco river basin, Brazil. Agricultural water management journal, 94, 31-42. http://dx.doi.org/10.1016/j.agwat.2007.08.001

Tsutsumi, A., Jinno, K., \& Berndtsson, R. (2004). Surface and subsurface water balance estimation by the groundwater recharge model and a 3-D two-phase flow model. Hydrological Sciences Journal, 49(2), 205-226.

Weerasinghe, K. D. N. (1986). Comparative study of temperature based equations in estimation of potential evapoteranspiration for Anguna-Kolapelessa in the arid zone of southern Sri Lanka. J. Natn. Sci. Coun. Sri lanka, 14(1), 75-82.

Xu, C. Y., \& Singh, V. P. (2001). Evaluation and generalization of temperature-based methods for calculating evaporation, Hydrol. Process, 15, 305-319.

Yunusa, I. A. M., Walker, R. R., \& Guy, J. R. (1997). Partioning of seasonal evapotranspiration from a commercial furrow irrigated Sultana vineyard. Irrig. Sci., $18, \quad 45-54$. http://dx.doi.org/10.1007/s002710050043 